\title{
Cruise Ships and Prison Camps: Reflections from the Russian Far East on Museums and the Crafting of History ${ }^{1}$
}

\author{
Alexia Bloch ${ }^{2}$
}

\begin{abstract}
In formerly socialist societies the state has dominated sites like museums viewed as critical for producing a national past, but in the case of the Russian Federation these same institutions often are being utilized now to critically examine the past. For many in the emerging market economy of the Russian Federation, formerly state-dominated sites like museums have become important economic resources as well as new sites for representing shifting concepts of history. In this article I examine the museum as an artifact of socialist and postsocialist society and consider how distinct political economies shape the ways in which cultural practices, as well as national and local histories, are depicted.
\end{abstract}

THE BROAD Literature on anthropology museums and museum displays that has burgeoned in the past decade often situates its critique in terms of the West and the "Other." This literature has defined the acquisition of objects from the periphery and the portrayal of peoples under glass as both representative of and an affirmation of the hegemony of the metropole (Stocking 1985, Clifford 1990, Hinsley 1992). Recently, however, scholars are taking note of the divergent aims and functions of museums as they operate in diverse national and local contexts. As a range of scholars has emphasized, museums are a potent force in forging and maintaining identities for newly emerging nations and for groups in postcolonial contexts (Kaplan 1994, Price and Price 1995, Schildkrout 1999).

The inadequacy of a model of cultural hegemony to describe the function of anthropology museums overall is especially revealed in socialist or recently socialist contexts. ("Anthropology museums" is used here to indicate a wide range of museums that could be identified as natural history, ethnography,

${ }^{1}$ Manuscript accepted 1 February 2001.

2 Department of Anthropology and Sociology, 6303 NW Marine Drive, University of British Columbia, Vancouver, B.C., Canada V6T 1Z1 (E-mail: abloch@ interchange.ubc.ca).

Pacific Science (2001), vol. 55, no. 4:377-387

(C) 2001 by University of Hawai'i Press

All rights reserved or local history museums. The emphasis is meant to be on those institutions that consider the representation of local, regional, or national history to be their mandate. In the Russian context, these museums are often called kraevecheskye muzei, or museums of regional studies.) Although the state has dominated sites like museums viewed as critical for producing a national past (Breckenridge 1989, Hinsley 1992, Watson 1994; A. E. Mendonça, "Company museums in the former Soviet Union," paper presented at the American Anthropological Association annual meetings in Philadelphia, December 1998), in the case of the Russian Federation these same institutions now are often being utilized to critically examine the past. Furthermore, for many an emerging market economy throws state-dominated sites like museums into relief as places where members of minority groups can continue to represent their past and thus consolidate community interests; this is especially important for indigenous groups often competing with various interests for control over natural resources. In drawing on research conducted in the late 1990s in several Siberian museums, this article examines a context of extreme flux in the directions anthropology museums are taking. Anthropology museums in Russia are inextricably part of the struggle over natural resources, the writing of local histories, and the general constitution of knowledge in a postsocialist society. In this article I examine the museum as an artifact of socialist and postsocialist societies reflecting 


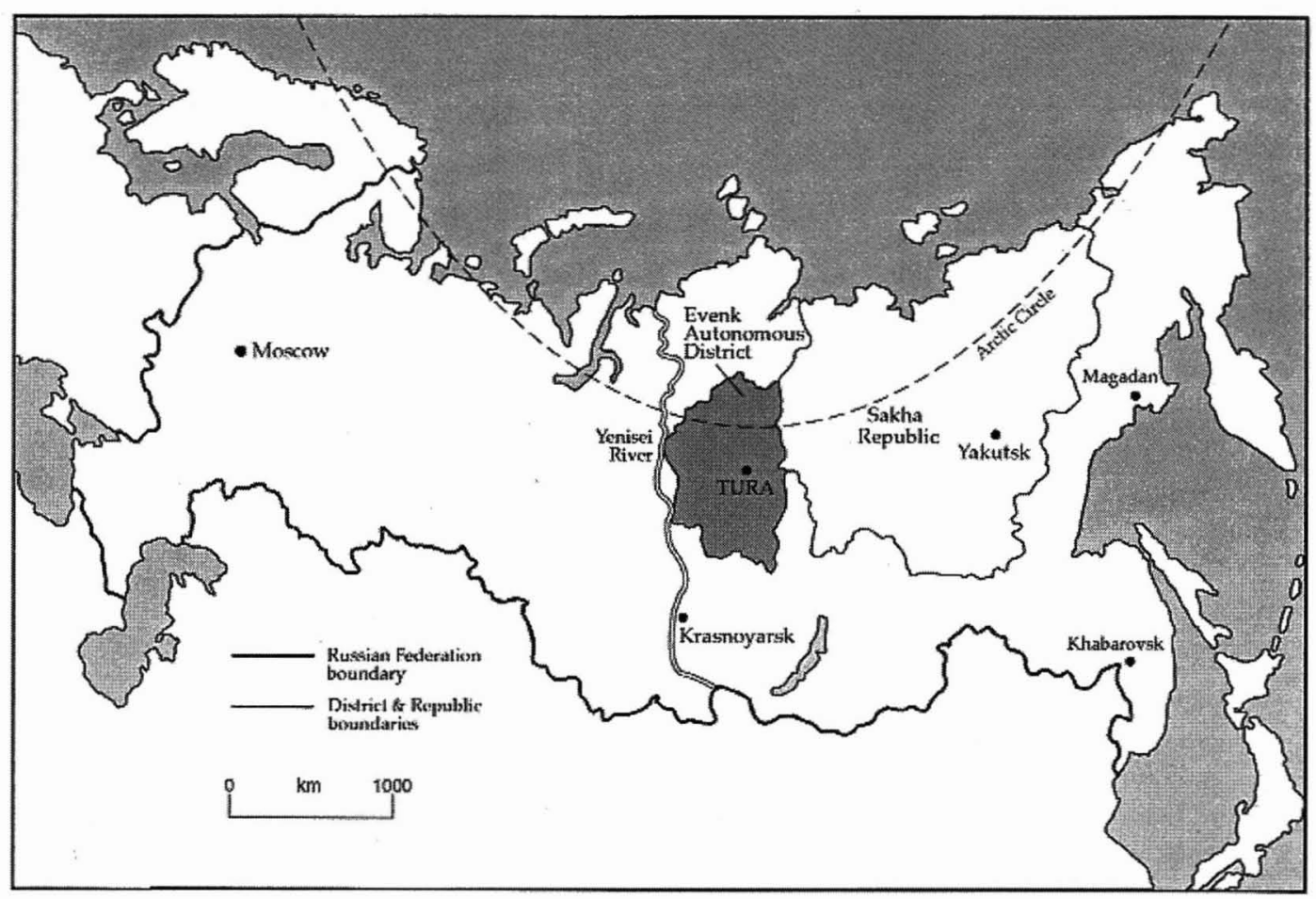

Figure 1. Map of Russia with the Evenk District shaded (Bridget Thomas, graphic designer, Department of Anthropology, American Museum of Natural History).

the distinct trajectory of a political economy in flux. In particular, this article focuses on three portraits of museum communities in Russia and considers what Siberian anthropology museums can tell us about broader issues concerning museums internationally.

THREE SIBERIAN MUSEUMS, THREE STORIES

Until recently, one of the unifying features of Russian (and earlier Soviet) natural history museums was the unilineal trajectory of development featured in them. As federal funding has diminished, and ideological constraints have also, this common feature is increasingly modified. Since 1991 and the dissolution of the Soviet Union, museums are no longer required to create exhibitions catering to Communist party dictates. Museum curators are free to design exhibits without the grand narrative that had defined their work for decades; they are able to set aside the grand narrative of progress tracing a tra- jectory of human development from hunting and gathering societies to a pinnacle of social and technological development. Although this new freedom enables some creative approaches and allows more space and time for other projects, in many cases it also leaves curators anxious about the alternative narratives that could frame their work. In comparing the cases of three Siberian museums, the elements of local political economy influencing the museum as a locus of knowledge production are highlighted. In this article I argue that by looking to anthropology or local history museums scholars can learn something about the ways in which communities are attempting to make sense of their past while positioning themselves for an uncertain future.

\section{The Evenk District Museum and Soviet State Narratives}

The first case for consideration is a museum in central Siberia, in a region called the 
Evenk Autonomous District (Figure 1). As across the North in Russia, the Evenki, an indigenous group traditionally practicing a mixed economy of reindeer herding and hunting and fishing, are a minority in their homeland. They are outnumbered by nearly one to five by European populations that began arriving in large numbers in the 1960s and $1970 \mathrm{~s}$ as part of the massive Soviet plans for resource extraction in the North (Fondahl 1993). The European population, primarily consisting of Russians and Ukrainians, was lured to the North by paychecks triple those in the southern urban centers. In contrast, the indigenous populations throughout Siberia were often displaced from their lands to make way for natural resource extraction or to simplify the supply and education of these communities (Bogoslovskaia 1993); they did not receive compensation.

Despite the widespread public outcry beginning in the late 1980s about conditions for indigenous peoples in the Russian North (Rytkheu 1988, Sangi 1988, Vakhtin 1994,
Abriutina 1997), in the 1990s the Evenk District Museum curiously continued to display the Soviet state's narrative that indigenous people prospered under socialism. (The research for this article was conducted during the summer of 1998. The portion on the Evenk District Museum grew out of my longterm ethnographic research in the Evenk District beginning in 1992. The portion on museums in the Russian Far East is based on a research trip in the summer of 1998 that I undertook along with Laurel Kendall, Asian curator at the American Museum of Natural History in New York. We set out to make contact with museums located in those communities where the Jesup North-Pacific Expedition conducted ethnographic, anthropometric, and linguistic research at the turn of the twentieth century.) The museum was divided into four permanent exhibition halls -natural history, human prehistory, ethnography, and Soviet history-along a classic evolutionary trajectory found in anthropology museums internationally (Figure 2). The ex-

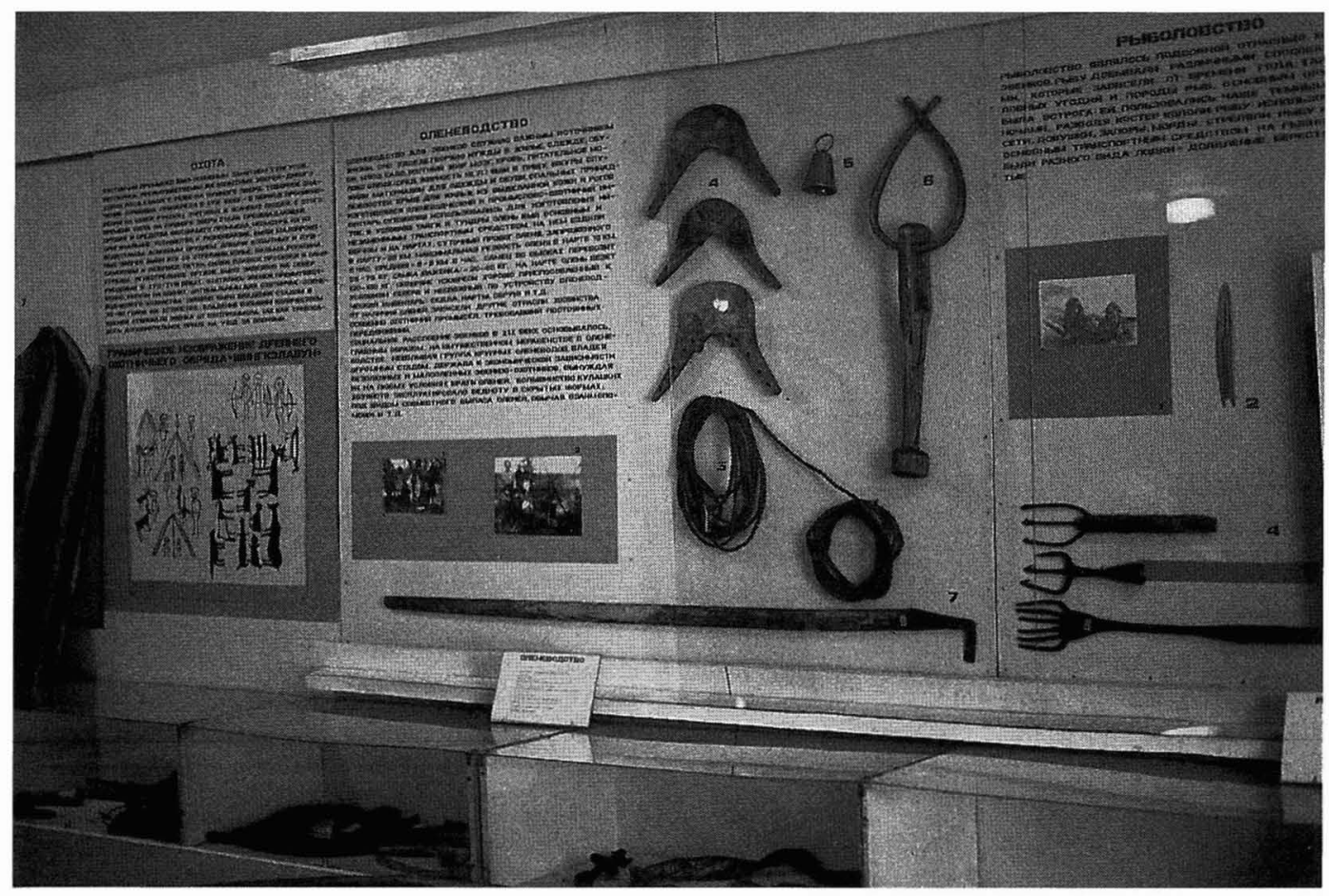

Figure 2. Evenk District Museum ethnography hall. Photographed by the author, June 1998. 
hibits in these halls were intended to provide an overall picture of the local history, including predictable images of the "progress" introduced in the Soviet era when industrialization in the North brought electricity, mining, and aviation. As in similar small government museums found throughout sparsely populated town centers in Siberia, material culture played a critical role in perpetuating social memory for the Evenk District community. The museum exhibits not only acted to remind residents of the former way of life for indigenous Siberians, but also linked the region and its inhabitants into the larger nation-state through a logic of industrial and evolutionary social progress. The social infrastructures, such as hospitals, schools, and collective farms established through the efforts of the Soviet state, became validated through this logic. This same teleological logic of industrialization was reflected in museum exhibits that could only place Evenk reindeer herders and subsistence fishers in the distant past as subjects for nostalgia. The complexity of lives intersected by contemporary struggles to maintain control of land for subsistence practices or efforts to combine wage labor in towns with subsistence practices remained unexamined in these exhibit halls. Instead the museum exhibits depicted the way in which indigenous populations "progressed" in the region as greater and greater numbers became literate, adopted sedentary lifestyles, and became inculcated with Soviet patriotism.

In the context of what Evenk elders tended to view as an onslaught of homogenizing market culture, in 1998 the Evenk District Museum continued to serve the role of preserving "local culture" and claiming for the Evenki what Virginia Dominguez has called "legitimacy through history" (1986:550). In other words, the museum was important because community leaders came to think of it as integrally tied to a recognition of their place in local history. Although the Evenk District Museum played a modest role in the general structure of government institutions in the region in the 1990s, it was an important symbolic site for the community. In existence since the early 1930s, the museum continued to serve as one of the important sites for a reiteration of nation-state power, despite a change in political power in the early 1990s and a virtual absence of financing since 1995. What was displayed as "traditional culture" fit into a narrative where the culture of the majority indigenous population in the region, the Evenki, was effortlessly and almost enthusiastically incorporated into the nation-state. (This version of history left out the painful elements of Evenk history, including collectivization in the 1930s, when reindeer herds were seized from those few households with more than 100 head, and the imposition of mandatory residential schooling beginning in the 1920s.)

The museum's centrally located Soviet history section reflected a continuous trajectory of Soviet nation-state consolidation. (Smaller museums in the Russian Far East in the late 1990s tended to uncritically continue in the exhibition traditions established in the late Soviet era. These featured a linear, proSoviet trajectory of social evolution, without any special indication of critiques of this history. In the larger museums in Khabarovsk and Magadan, however, some dominant paradigms of the Soviet period were severely questioned. In the case of Khabarovsk, the museum director explained how the museum had dismantled the permanent exhibit halls featuring the establishment of Soviet power and instead created two new halls, one dedicated to nineteenth-century and the other to twentieth-century local history.) This consolidation was evident in label copy such as the following: "The Onset of Socialist Society in the North," "Collectivization of Agriculture in Evenkiia, 1930-1940," "[Communist] Party Organizing in Evenkiia," "The Establishment of Aviation," "Evenkiia Defending the Fatherland," and "The End of the War and the Return to Peacetime Activities." Black-and-white photos and text taken from local newspaper accounts accompanied these labels. For instance, one photo featured a local Evenk man who became a national hero for his celebrated role in defending the Western front against the German incursion during World War II (Figure 3).

What was most striking about these displays was how much was left uncritically ex- 


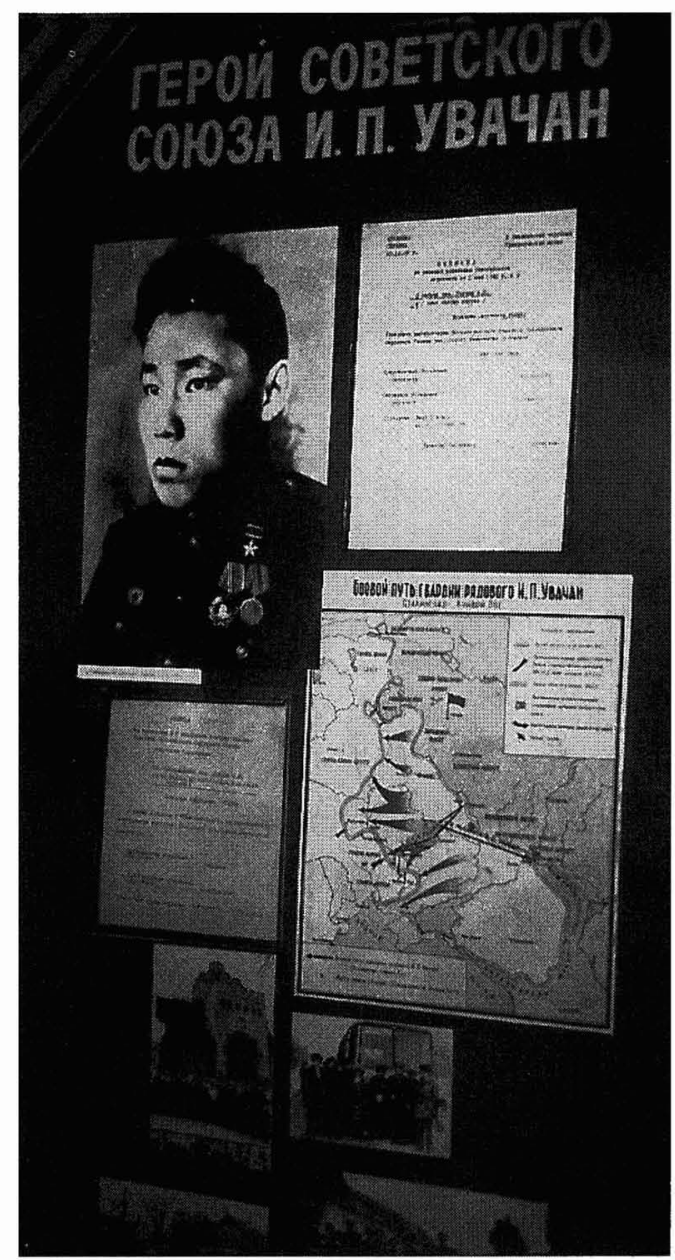

FIgURE 3. Image of I. P. Uvachan, Soviet World War II hero. Photographed by the author in the Evenk District Museum, June 1998.

amined. The official Soviet version of local history continued as the dominant theme in this museum. One particularly vivid example was a display of an early 1930s ledger from a regional council meeting. It read, "In 193132 ...268 Evenk representatives were elected to the council; among them there were 186 'poor' [Evenk], 14 'hired' [Evenk], and 68 [Evenk] 'of average means.'" There was no effort to contextualize this statement and explain that along with the Soviet efforts to classify the population for purposes of pitting groups against one another, even in this small town, at least 20 people were widely believed to have been executed, and others suffered for resisting the state's efforts to reorganize production patterns. (See Slezkine [1994] for an extensive discussion of this period in the Soviet North.) By eliding this type of context, the emphasis was instead shifted to commemorating Soviet efforts to expand the inclusion of Evenki in local political life.

The lack of commentary throughout the museum exhibits on the varied successes of local Soviet efforts to establish and maintain control over the population suggested the ongoing ambivalences of a contemporary indigenous elite that experienced a range of benefits in the Soviet era. Although there were segments of the local population quietly exploring for themselves the ruptures in recent history, the museum continued to largely disregard the ruptures in favor of reproducing a seamless social memory from a Soviet past. (In June 1998, I met with a local Sakha woman who was eager to share with me documents regarding her family's 1938 "kulakization" and subsequent 1996 official government rehabilitation. Her father was accused of harboring "anti-Soviet" attitudes in 1938 because he was thought to have too many reindeer. According to recent Russian Federal legislation, rehabilitated persons and their direct family members were to receive a symbolic monetary compensation for the unjust treatment they received in 1938 and for years later. In the late 1990s Evenk District legislation also dedicated financial support for such persons to receive gratis housing in Krasnoyarsk, the closest major city, located to the south of the Evenk District.)

\section{The Magadan Museum and Portraying the Past in a New Light}

Visiting the Magadan Regional History Museum, I was struck by how it presented history so differently from the Evenk District Museum just discussed. The material contrasts could be attributed to institutional size and better funding; the mayor of Magadan, a sizeable city and important trade center, had recently funded two new permanent exhibits (Figure 4). 


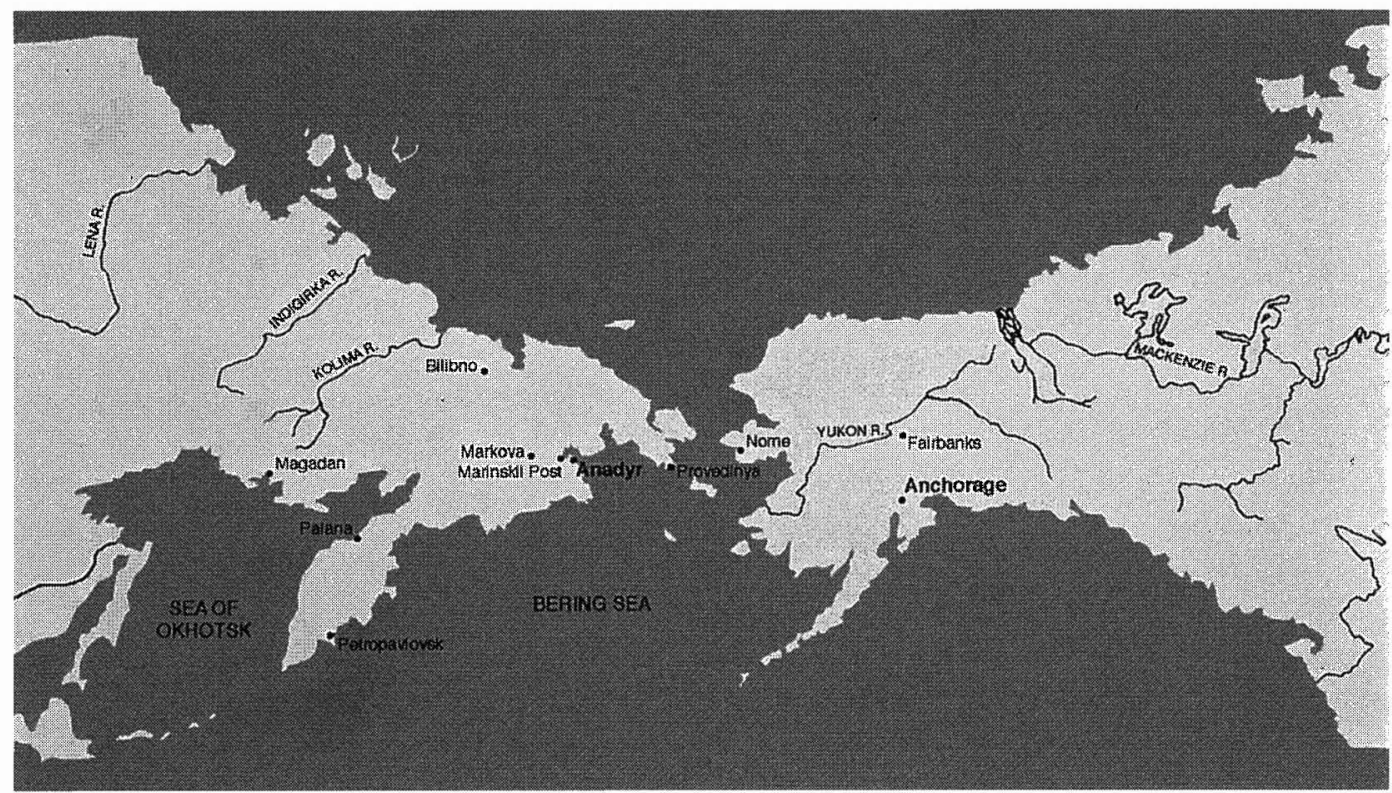

Figure 4. Map of the Russian Far East (Bridget Thomas, graphic designer, Department of Anthropology, American Museum of Natural History).

However, the museum also demonstrated a pleasing aesthetic sense, with a new, airy natural history hall and carefully crafted, individually fitted clear plastic supports for museum objects on display (Figure 5). Furthermore, there was striking attention given to the artisans who had crafted objects on display; in the case of one exhibit on contemporary ivory carvings, photographs and brief biographies of the artisans were featured in the center of the hall.

Although the museum adhered to the general evolutionary framework defining Russian regional history museums-with natural history, ethnology, and Soviet history halls - it also departed from the familiar scripts by including contemporary art exhibits and temporary exhibits featuring painful aspects of recent history, such as the Kolyma prison camps. This latter exhibit was extensively researched by the museum staff, who interviewed former prisoners, collected correspondence, and obtained "artifacts" such as mining equipment and shackles from the former prison colony. This exhibit was spurred by the historical moment when such research and public debate was suddenly welcomed with the fall of the Soviet Union in 1991. Furthermore, the exhibit came about within the new financial confines of museology where travel to distant field sites was not forthcoming from the Ministry of Culture in Moscow. Curators were compelled to look closer to home for their subjects for historical inquiry.

In discussing museological issues with colleagues at this museum, many described a lost sense of mission with the demise of the social evolutionary paradigm that had guided $\mathrm{mu}-$ seum research, exhibition, and education for decades. In the course of spirited discussion among the scientific staff concerning the past and the future goals of the museum, those present agreed that the Leninist program of the past was inappropriate because it did not adequately explain the dynamic reality of the present or make sense of the past as lived by people in the region. Still, a few museum colleagues felt some nostalgia for the past system, as one woman explained while dabbing tears from her eyes. The staff seemed frustrated without a concrete paradigm for 


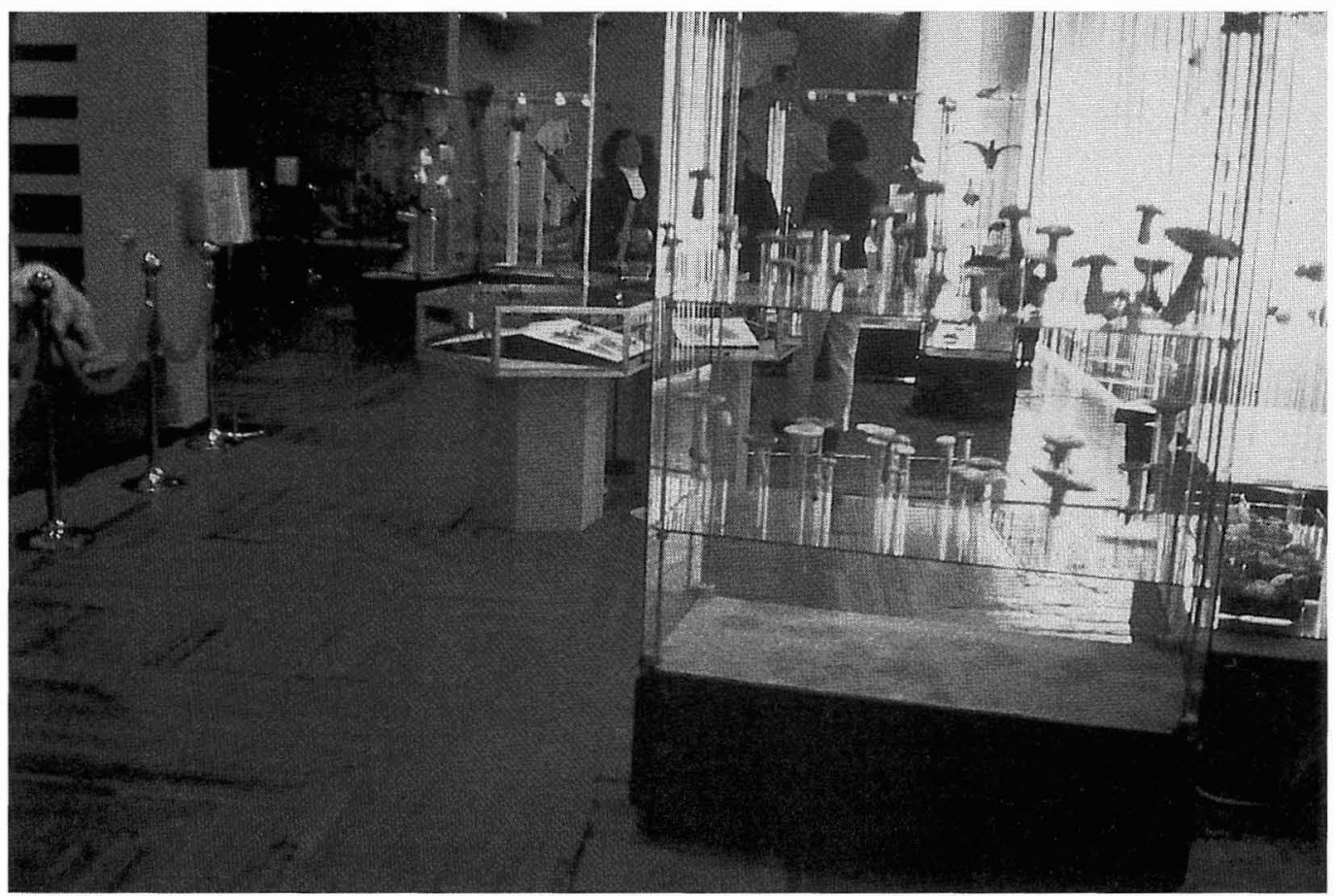

FIGURE 5. Natural history hall with mushroom exhibit, Magadan. Photographed by the author, August 1998.

directing their ongoing work, but they were not floundering and had already come up with creative, provocative topics for research and future exhibits, such as collecting materials on the recent elections in the area. As one scientific staff member explained, "The election process is all new for us and it is important to share this experience with people in the future."

\section{Provideniia Museum and Encountering the Market}

It is tempting to describe the very different approaches being taken in the Magadan and Evenk Museums in terms of a divide related to size and social position vis-à-vis the surrounding community. (After all, the Magadan Museum is cosmopolitan and located in a relatively large city of nearly one million, whereas the Evenk Museum caters to a small population in a town of just 6000.) At first glance James Clifford's distinction between "tribal" and "majority" museums (1990) in some ways applies to the Russian museum context and helps explain some of the very different approaches to museology found in the Russian regional history museums. However, as a third and final example demonstrates, this binary distinction overly simplifies the ways these museums are encountering change; museum approaches to portraying the past and present in Siberia and the Russian Far East are more closely linked to political economy than to a simple divide between European and native concerns.

The Provideniia Museum of Regional History is located in a town of 3000 people, just across the Bering Strait and a 45-minute flight from Nome, Alaska (Figure 6). Like the Evenk District Museum, in 1998 the Provideniia Museum was a modest enterprise with just three employees. The museum consisted of several rooms that presented the history of the Yupik Eskimo, Chukchi, and Europeans living in the region. Like the staff in the more 


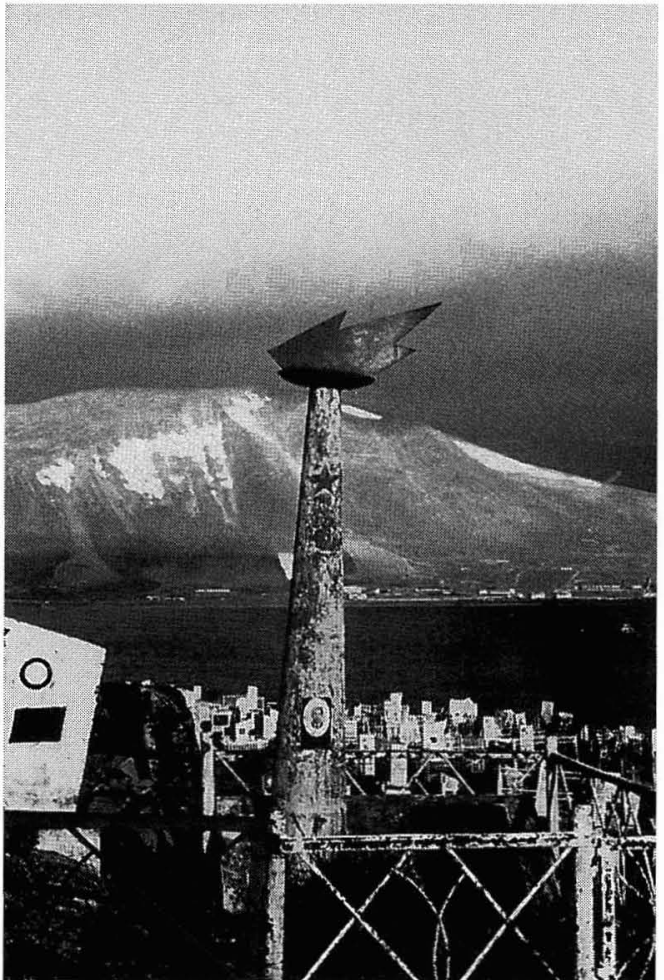

Figure 6. A view toward Dezhnev Bay, Provideniia, Russia. Photographed by the author, August 1998.

metropolitan museum in Magadan, however, the staff in the museum was actively redefining its approach to documenting, preserving, and interpreting local history following the fall of the Soviet Union.

In 1998 the Provideniia Museum departed from a familiar Soviet narrative of socialist development and the dominant themes of government achievements in medicine, schooling, and aviation. Rather than maintain exhibits created in the Soviet era emphasizing evolutionary trajectories and eliding tragic events in local experience, this museum sought out new ways to represent the contemporary lives and past of the region. Two of the four exhibition halls featured contemporary local artists' work in painting and photography taken in local villages; this was professionally displayed in handmade frames, with careful attention to the accompanying lighting. Two other halls were dedicated to archaeology and ethnology of the region, and again the attention to aesthetics was striking, especially considering the limited finances. In this context even purchasing a lightbulb or index cards for documentation of collections was difficult, let alone obtaining acid-free materials for preservation. Despite this situation, the dedicated museum director had ingeniously turned an old card catalog into storage for archaeological artifacts.

In general, a critical eye toward local history and culture took the place of simply reiterating a Soviet version of local history. A set of Lenin's works and an old black rotary phone lay on a free surface waiting to be acquisitioned by museum staff; the museum director explained that both were important for the museum's ethnology collections and would be used in exhibits on the recent Soviet period. In a similar spirit of creative exhibitions, the museum looked to community members as important resources. The museum director often consulted with local Eskimo and Chukchi elders in designing exhibits and involved them as consultants in research projects. For instance, in recent years the staff was involved in consulting elders in analyzing artifacts excavated from the sites of so-called "lost villages," or communities forcibly relocated from strategic locations during the Cold War.

The emphasis on representing history in this small museum was not by chance. The museum director's creative energy was certainly a factor, but so too was political economy. Both the Evenk and Provideniia Museums are situated in contexts of a small regional center with an indigenous population outnumbered five to one by a European population. However, the larger geographic locations are very different and result in disparate financial opportunities. The Evenk Museum is located in central Siberia, in an area that is difficult and expensive to get to and with less appeal for tourists than that of the Bering Strait region. The Provideniia Museum is ideally located, both for tourism from Alaska and for visits by cruise ships.

The new political economy coupled with failing Russian government support for museums has led to an intensified commoditiza- 
tion of "traditional" cultures in areas where tourism is successful, a situation described in classic analyses of the impact of tourism on indigenous political economies (Graburn 1976). Without tourism, the Provideniia Museum would not be operating. In 1998 the museum charged a $\$ 20$ admission for foreign tourists; this included a slide show featuring the stunning Arctic habitat of the region, folk dance performances by local Yupik Eskimo and Chukchi elders and children, and takehome souvenirs of fur and mammoth bone. Although during the winter there are few if any nonlocal visitors to the museum, in the summer months, when international cruise ships and a few individual tourists visit the area, as many as 2000 people visit the museum. In 1998 in a context where the museum no longer received government monies of any significance, it was not surprising that the institution was formulating a different type of message in its exhibitions. Just as Fred Meyers (1994) noted in reflecting on Australian Aborigines performing at the Asia Society in New York, the "performance of aboriginality" was a key element in this museum. In the case of the Provideniia Museum, the "performance of aboriginality" only became a conscious and essential aspect of the revenue for the museum in the early 1990s; by extension, cultural performance or "cultural tourism" became a new feature of subsistence practice for the broader Yupik Eskimo and Chukchi communities and continues to be important.

The shifting political economy of postsocialism was key in defining museum practice in yet another way. With Alaska just across the Bering Strait, the museum was able to benefit from the boom in research into the cultural ecology of the North Pacific and specifically the Bering Sea Region (World Wildlife Fund 2000). For several years in the late 1990s the museum acted as a partner in cultural ecology exchanges and research. For instance, in 1998, in exchange for arranging whale-counting sites along the Bering Sea for their Alaska partners in Barrow, the museum received monies for purchasing a computer. The Yupik Eskimo and Chukchi residents who engaged in counting the whales received much-needed gasoline and oil for powering boats for hunting and transport. Thus, in the late 1990s the Provideniia Museum of Regional History found itself in a new position as a community locus, a position not determined by funding from Moscow, but from funding flowing from across the Bering Strait.

RUSSIAN MUSEUMS IN MOTION: COMMON CRISIS OR UNIQUE CROSSROADS?

No matter how museums in Russia resolve their particular crisis of mission and financial dilemmas, the very fact that museums are faced with redefining what it means to represent local history and with reframing their engagement with the surrounding community is instructive for broader considerations of cultural processes. Many natural history museums in Siberia are at the forefront of waves of change for museum practice worldwide. The active efforts to collaborate with native elders in research projects, consult with community members in designing exhibits, and engage elders in discussing and reflecting on artifacts are reminiscent of similar projects in New Zealand, North America (Gorbey 1992, Mahuika 1992), and elsewhere. Like their counterparts in other contexts, Russian museums are caught up in a time of significant change; although this is not necessarily playing out in the same concrete ways, museums around the Pacific Rim and beyond are faced with resolving just what a museum should be, how to represent subjects respectfully, and to what degree to commoditize material culture en route to ensuring economic viability of an institution. As loci of knowledge production and dissemination, anthropology museums across the world are enmeshed in their local political economies. The Siberian examples remind us of both the variation in museum practice caused by shifting sociopolitical factors and the common challenges to museum practice as it emerges in the twenty-first century.

In thinking about Russian museums, we can gain valuable insight into cultural processes of postsocialism and specifically into the vivid reframing of history that is now 
taking place in the Russian Far East and former Soviet Union overall. There could hardly be a more vivid lesson in the social constructions of historical representation and the impact of market relations on the shifting role of material culture in these representations. One could easily imagine hearing the comments of one of the museum professionals in Magadan from museum professionals in other locations in the world; as the Magadan historian lamented, "We just don't know what the frameworks are anymore." Perhaps the moment of crisis for anthropology museums worldwide will turn out to be a crossroads where knowledge comes to be reconstituted and local practices can be interpreted from a range of divergent perspectives. If the experience of the Provideniia Museum is any indication of the future, it appears that in the shifting political economies of the twentyfirst century the commoditization of local material culture does not necessarily have to result in versions of Disney World. Ironically, however, with the cutbacks in Russian Federation revenues for regional cultural institutions, local history museums are left scrambling for funds and waiting for cruise ships so that they can finance critical reinterpretations of recent Soviet historical experience.

\section{Literature Cited}

Abriutina, Larisa. 1997. Narody Severa. Problemy, analiz prichin i perspektivy ikh preodoleniia. Zhivaia Arktika 2-4 (6-8): 16-23.

Bogoslovskaia, Liudmilla. 1993. List of the villages of the Chukotka Peninsula (2000 в.P. to present). Beringian Notes 2:2. 7 December. U.S. National Park Service.

Breckenridge, Carol A. 1989. The aesthetics and politics of colonial collecting: India at World Fairs. J. Soc. Hist. 31 (2): 195216.

Clifford, J. 1990. Four Northwest Coast museums. Pages 112-254 in Ivan Karp and S. D. Lavine, eds. Exhibiting cultures: The poetics and politics of museum display. Smithsonian Institution Press, Washington, D.C.
Dominguez, Virginia R. 1986. The marketing of heritage. Am. Ethnol. 13 (3): 546-555.

Fondahl, Gail A. 1993. Siberia: Native peoples and newcomers in collision. Pages 477-510 in Ian Bremmer and Ray Taras, eds. Nations and politics in the Soviet successor states. Cambridge University Press, Cambridge.

Gorbey, Ken. 1992. The challenge of creating a bicultural museum. Mus. Anthropol. 15 (4): 7-8.

Graburn, Nelson H. H., ed. 1976. Ethnic and tourist arts: Cultural expressions from the Fourth World. University of California Press, Berkeley.

Hinsley, Curtis M. 1992. Collecting cultures and cultures of collecting: The lure of the American Southwest, 1880-1915. Mus. Anthropol. 16 (1): 12-20.

Kaplan, Flora E. S., ed. 1994. Museums and the making of "ourselves": The role of objects in national identity. Leicester University Press, London.

Mahuika, Apirana T. 1992. Maori culture and the new museum. Mus. Anthropol. 15 (4): 9-11.

Meyers, Fred. 1994. Culture-making: Performing aboriginality at the Asia Society Gallery. Am. Anthropol. 21 (4): 679-699.

Price, Richard, and Sally Price. 1995. Enigma variations. Harvard University Press, Cambridge, Massachusetts.

Rytkheu, Yuri. 1988. Slogany I amulety. Komsomolskaya Pravda. 19 May.

Sangi, V. 1988. Ochuzhdeniia. Sovetskaya Rossiya. 11 November.

Schildkrout, Enid. 1999. Royal treasury, historic house, or just a museum? Transforming Manhyia Palace, Ghana, into a site of cultural tourism. Mus. Anthropol. 22 (3): 14-27.

Slezkine, Yuri. 1994. Arctic mirrors: Russia and the small peoples of the North. Cornell University Press, Ithaca, New York.

Stocking, George W. 1985. Introduction. Pages 3-14 in George W. Stocking, ed. Objects and others: Essays on museums and material culture. University of Wisconsin Press, Madison.

Vakhtin, Nikolai. 1994. Native peoples of the Russian Far North. Pages 29-80 in Mi- 
nority Rights Group, ed. Polar peoples: World Wildlife Fund. 2000. The Bering Sea Self-determination and development. Minority Rights Publications, London.

Watson, Rubie S. 1994. Palaces, museums, and squares: Chinese national spaces. Mus. Anthropol. 19 (2): 7-17. Ecoregion. Public Information Report produced by World Wildlife Fund and Beringia Conservation Program, Washington, D.C. 